Original Research Paper

\title{
Thermal Performance Assessment for Laminar Forced Convection with Downstream Reformed-V and Reformed- Double-V Generators
}

\author{
${ }^{1}$ Withada Jedsadaratanachai and ${ }^{2}$ Amnart Boonloi \\ ${ }^{I}$ Department of Mechanical Engineering, Faculty of Engineering, King Mongkut's Institute of Technology Ladkrabang, \\ Bangkok 10520, Thailand \\ ${ }^{2}$ Department of Mechanical Engineering Technology, College of Industrial Technology, King Mongkut's University of \\ Technology North Bangkok, Bangkok 10800, Thailand
}

\author{
Article history \\ Received: 2014-04-04 \\ Revised: 2014-10-30 \\ Accepted: 2014-11-12 \\ Corresponding Author: \\ Amnart Boonloi, \\ Department of Mechanical \\ Engineering Technology, \\ College of Industrial \\ Technology, \\ King Mongkut's University of \\ Technology North Bangkok, \\ Bangkok 10800, Thailand \\ Email: amp_g7@hotmail.com
}

\begin{abstract}
Thermal assessments for laminar flow in an isothermal wall square channel over downstream Reformed-V (RV) and Reformed-Double-V (RDV) generators inserted diagonally are presented numerically in three dimensional. The RV and RDV are designed to comfort for forming and installing in the heat exchanger channel. The effect of RV and RDV height is investigated in terms of blockage ratio, $\mathrm{b} / \mathrm{H}, \mathrm{BR}=0.05-0.30$ for Reynolds number based on the hydraulic diameter of the square channel, $\mathrm{Re}=100-1200$. The SIMPLE algorithm, finite volume method and the periodic condition are used in the current computational domain. The mathematical results show that the uses of RV and RDV provide higher heat transfer rate than the smooth square channel with no generators. The $\mathrm{RV}$ gives higher on both heat transfer rate and friction factor values than the RDV case for all BR and Re values. The maximum heat transfer rate and friction factor are found around 20.5 and 420 times over the smooth square channel, respectively, at $\mathrm{BR}=0.30$ for $\mathrm{RV}$ case. The optimum thermal enhancement factor, TEF, is found at $\mathrm{BR}=0.1, \mathrm{Re}=2000$ around 2.95 for $\mathrm{RDV}$ case.
\end{abstract}

Keywords: Forced Convection, Generators, Laminar Flow, Periodic Condition, Thermal Enhancement Factor

\section{Introduction}

The installation of the vortex generators is widely use in heat exchanger channel to improve the thermal performance. The $\mathrm{V}$-shaped vortex generators are usually applied in the heat system, because it can create the impinging jet over the channel lead to the augmenting heat transfer rate and also increasing the thermal performance. However, the uses of the generators are remained the problems, such as; the installation method, the forming and the optimized generators shape, etc.

The investigations on the generators had been reported on both experimental and numerical. The numerical results can explain the phenomena of the flow structure that the way to develop the generators for occurring the maximum point of thermal enhancement factor. Therefore, this work is focused on the investigation with the numerical method. The Table 1 shows the numerical study of the vortex generators in heat transfer system.
Due to the forming and the installation of the generators in the heat exchanger channel are very important factors for industrial system, thus, the modified generators for comfortable to install had been investigated. The gaps which decreased the thermal performance and heat transfer rate were found when using the generators placed on the channel walls. The new designs of the generators which inserted diagonally in the square channel are interesting.

The major research objectives are as follows:

- To obtain numerical solutions for the heat exchanger channel with Reformed-V (RV) and ReformedDouble-V (RDV) vortex generators

- To explain the mechanism of heat transfer augmentation and flow visualization in square channel for the laminar forced convection regime

- To evaluate the thermal performance by using the $\mathrm{RV}$ and RDV generators 
Table 1. The investigations of the vortex generators with numerical method

\begin{tabular}{|c|c|c|c|c|}
\hline Authors & Studied cases & $\mathrm{Nu} / \mathrm{Nu}_{0}$ & $\mathrm{f} / \mathrm{f}_{0}$ & TEF \\
\hline $\begin{array}{l}\text { Jedsadaratanachai et al. } \\
\text { (2011) }\end{array}$ & $\begin{array}{l}30^{\circ} \text { inclined baffle } \\
\text { Inline, two opposite walls, square channel } \\
B R=0.2 \\
P R=0.5-2.5 \\
\operatorname{Re}=100-2000\end{array}$ & $1.00-9.20$ & $1.00-21.50$ & 3.78 \\
\hline $\begin{array}{l}\text { Kwankaomeng and } \\
\text { Promvonge (2010) }\end{array}$ & $\begin{array}{l}30^{\circ} \text { inclined baffle } \\
\text { One side, square channel } \\
\mathrm{BR}=0.1-0.5 \\
\mathrm{PR}=1.0-2.0 \\
\operatorname{Re}=100-1000\end{array}$ & $1.00-9.23$ & $1.09-45.31$ & 3.10 \\
\hline Promvonge et al. (2010a) & $\begin{array}{l}30^{\circ} \text { inclined baffle } \\
\text { Inline, two opposite walls, square channel } \\
\mathrm{BR}=0.1-0.3 \\
\mathrm{PR}=1.0-2.0 \\
\operatorname{Re}=100-2000\end{array}$ & $1.20-11.00$ & $2.00-54.00$ & 4.00 \\
\hline $\begin{array}{l}\text { Promvonge and } \\
\text { Kwankaomeng, (2010) }\end{array}$ & $\begin{array}{l}45^{\circ} \text { V-baffle } \\
\text { Staggered, two opposite walls, } A R=2 \text { channel } \\
B R=0.05-0.3 \\
P R=1.0 \\
\operatorname{Re}=100-1200\end{array}$ & $1.00-11.00$ & $2.00-90.00$ & 2.75 \\
\hline Promvonge et al. (2010b) & $\begin{array}{l}45^{\circ} \text { inclined baffle } \\
\text { Inline-staggered, two opposite walls, square channel } \\
\mathrm{BR}=0.05-0.3 \\
\mathrm{PR}=1.0 \\
\mathrm{Re}=100-1000\end{array}$ & $1.50-8.50$ & $2.00-70.00$ & 2.60 \\
\hline Promvonge et al. (2012) & $\begin{array}{l}45^{\circ} \text { V-baffle } \\
\text { Inline downstream, two opposite walls, square channel } \\
B R=0.1-0.3 \\
P R=1.0-2.0 \\
\operatorname{Re}=100-2000\end{array}$ & $1.00-21.00$ & $1.10-225.00$ & 3.80 \\
\hline Boonloi (2014) & $\begin{array}{l}20^{\circ} \mathrm{V} \text {-baffle } \\
\text { Inline downstream-upstream, two opposite walls, } \\
\text { square channel } \\
\mathrm{BR}=0.1-0.3 \\
\mathrm{PR}=1.0 \\
\mathrm{Re}=100-2000\end{array}$ & $1.00-13.00$ & $1.00-52.00$ & 4.20 \\
\hline $\begin{array}{l}\text { Boonloi and } \\
\text { Jedsadaratanachai (2013) }\end{array}$ & $\begin{array}{l}30^{\circ} \text { V-baffle } \\
\text { Downstream, one side, square channel } \\
\mathrm{BR}=0.1-0.5 \\
\mathrm{PR}=1.0-2.0 \\
\operatorname{Re}=100-1200\end{array}$ & $1.00-14.49$ & $2.18-313.24$ & 2.44 \\
\hline $\begin{array}{l}\text { Jedsadaratanachai and } \\
\text { Boonloi (2013) }\end{array}$ & $\begin{array}{l}45^{\circ} \text { Discrete-V-baffle } \\
\text { Downstream, diagonally, square channel } \\
\mathrm{BR}=0.05-0.20 \\
\mathrm{PR}=1.0-1.5 \\
\mathrm{Re}=100-1200\end{array}$ & $1.40-8.10$ & $2.50-36.00$ & 2.50 \\
\hline $\begin{array}{l}\text { Jedsadaratanachai and } \\
\text { Boonloi (2014) }\end{array}$ & $\begin{array}{l}\text { Single twisted tape } \\
\mathrm{y} / \mathrm{W}=1.0-6.0 \\
\mathrm{Re}=100-2000\end{array}$ & $1.00-10.00$ & $3.00-44.00$ & 3.51 \\
\hline
\end{tabular}

\section{Boundary Conditions and Assumptions}

The boundary conditions and the assumptions of current mathematical models which referred from Promvonge et al. (2012) are as follows:
- The periodic boundaries are used for inlet and outlet of the domain

- $\quad$ The tested fluid is air with a temperature of $300 \mathrm{~K}$ $(\mathrm{Pr}=0.7)$ and enter to the inlet with constant mass flow rate 
- The inlet and outlet velocity profiles must be identical

- The physical properties of the air have been assumed to remain constant at average bulk temperature

- Impermeable boundary and no-slip wall conditions have been implemented over the square channel walls as well as the twisted tape

- The constant temperature of the channel walls is maintained at $310 \mathrm{~K}$ while the $\mathrm{RV}$ and $\mathrm{RDV}$ is assumed at adiabatic wall conditions

- Steady three-dimensional fluid flow and heat transfer

- The flow is laminar and incompressible

- Constant fluid properties

- Body forces and viscous dissipation are ignored.

- Negligible radiation heat transfer

\section{Computational Domains, Grid Independent} Test and Validation of the Smooth Channel

Figure 1 shows the square channel geometry with $\mathrm{RV}$ and RDV generators inserted diagonally. The

square channel height, $\mathrm{H}$ is set equal to $0.05 \mathrm{~m}, \mathrm{~b}$ is defined as the generators height, $\mathrm{b} / \mathrm{H}$ is known as the blockage ratio. The spacing of the generators, $\mathrm{P}$ and $\mathrm{P} / \mathrm{H}$ is identified as the pitch ratio of the generators. The distance from generators edge to tip is fixed at $0.5 \mathrm{H}$ on both $\mathrm{RV}$ and RDV. The case studies are presented as Table 2 .

The characteristics of three grids; such as 80000 , 120000 and 180000 cells, are adopted in the simulations for using the Grid Convergence Index (GCI) (Roache, 1998). The numerical results show similar trends and values on both $\mathrm{Nu}$ and $\mathrm{f}$ when using 120000 and 180000 cells. Therefore, the computational domain is set 120000 cells of the grid system for this work.

Table 2. Case studies

\begin{tabular}{llll}
\hline Case & BR & PR & Re \\
\hline RV & $0.05-0.30$ & 1.00 & $100-1200$ \\
RDV & $0.05-0.30$ & 1.00 & $100-1200$ \\
\hline
\end{tabular}
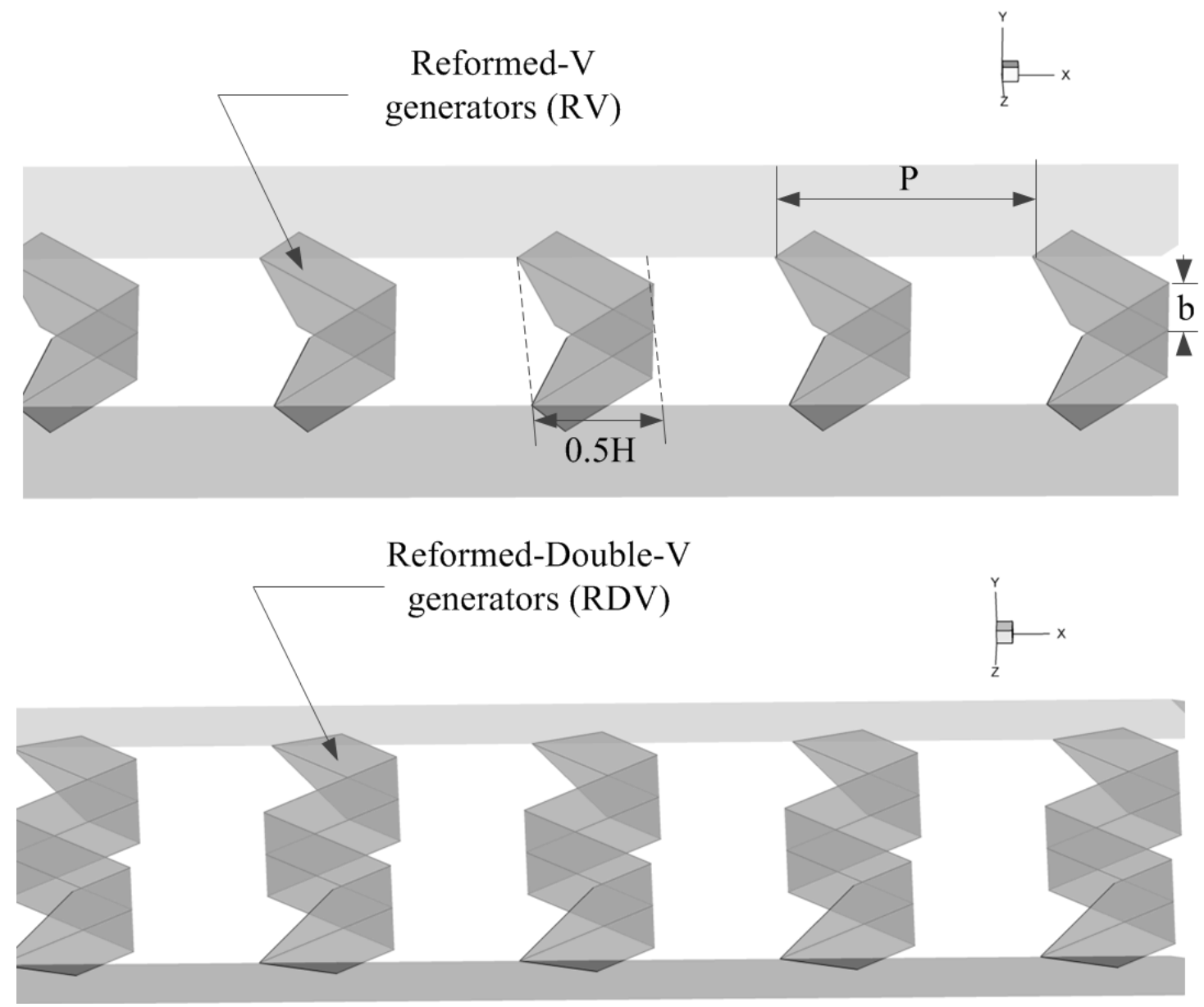

Fig. 1. Square channel geometry for RV and RDV generators 
Table 3. Validation of smooth square channel

\begin{tabular}{|c|c|c|c|c|c|c|}
\hline \multirow[b]{2}{*}{$\operatorname{Re}$} & \multicolumn{2}{|c|}{ Exact solution } & \multicolumn{2}{|c|}{ Present prediction } & \multicolumn{2}{|c|}{ Error $(\%)$} \\
\hline & $\mathrm{Nu}$ & $\mathrm{f}$ & $\mathrm{Nu}$ & $\mathrm{f}$ & $\mathrm{Nu}$ & $\mathrm{f}$ \\
\hline 100 & 2.98 & 0.57000 & 2.978 & 0.5710 & 0.0671 & -0.1754 \\
\hline 200 & 2.98 & 0.28500 & 2.975 & 0.2880 & 0.1678 & -1.0526 \\
\hline 300 & 2.98 & 0.19000 & 2.981 & 0.1910 & -0.0336 & -0.5263 \\
\hline 400 & 2.98 & 0.14250 & 2.983 & 0.1430 & -0.1007 & 0.0000 \\
\hline 500 & 2.98 & 0.11400 & 2.983 & 0.1120 & -0.1007 & 1.7544 \\
\hline 600 & 2.98 & 0.09500 & 2.981 & 0.0950 & -0.0336 & 0.0000 \\
\hline 800 & 2.98 & 0.07125 & 2.988 & 0.0710 & -0.2685 & 0.3509 \\
\hline 1000 & 2.98 & 0.05700 & 2.988 & 0.0570 & -0.2685 & 0.0000 \\
\hline 1200 & 2.98 & 0.04750 & 2.988 & 0.0475 & -0.2685 & 0.0000 \\
\hline
\end{tabular}

The numerical results on both $\mathrm{Nu}$ and $\mathrm{f}$ are compared among the present prediction and the exact solution under similar operating conditions. The result is found to be in excellent agreement with exact solution values obtained from the open literature (Incropera and Dewitt, 2006) for both the $\mathrm{Nu}$ and $\mathrm{f}$, less than $\pm 1.75 \%$ deviation as shown in Table 3. The exact solutions of $\mathrm{Nu}$ and $\mathrm{f}$ for laminar flow over plain square channel are presented as Equation 1 and 2, respectively:

$N u_{0}=2.98$

$f_{0}=\frac{64}{\operatorname{Re}}$

\section{Mathematical Foundation}

The mathematical foundations for the current work are referred from Promvonge et al. (2012). The continuity equation, the momentum equation and the energy equation can be written as follows:

Continuity Equation 3:

$$
\frac{\partial}{\partial x_{i}}\left(\rho u_{i}\right)=0
$$

Momentum Equation 4:

$$
\frac{\partial\left(\rho u_{i} u_{j}\right)}{\partial x_{j}}=-\frac{\partial p}{\partial x_{i}}+\frac{\partial}{\partial x_{j}}\left[\mu\left(\frac{\partial u_{i}}{\partial x_{j}}+\frac{\partial u_{j}}{\partial x_{i}}\right)\right]
$$

Energy Equation 5:

$$
\frac{\partial}{\partial x_{i}}\left(\rho u_{i} T\right)=\frac{\partial}{\partial x_{j}}\left(\Gamma \frac{\partial T}{\partial x_{j}}\right)
$$

where, $\Gamma$ is the thermal diffusivity and is given by:

$$
\Gamma=\frac{\mu}{\operatorname{Pr}}
$$

Except from the energy equation discretized by the QUICK scheme, the governing equations were discretized by the Second Order Upwind (SOU) scheme, decoupling with the SIMPLE algorithm and solved by using a finite volume approach (Patankar, 1980). The solutions are measured to be converged when the normalized residual values were less than $10^{-5}$ for all variables but less than $10^{-9}$ only for the energy equation.

The parameters; Reynolds number, friction factor, Nusselt number, average Nusselt number and thermal enhancement factor are presented as Equation 7 to 11 , respectively:

$$
\begin{aligned}
& \operatorname{Re}=\rho \bar{u} D / \mu \\
& f=\frac{(\Delta p / P) D}{\frac{1}{2} \rho \bar{u}^{2}} \\
& N u_{x}=\frac{h_{x} D}{k} \\
& N u=\frac{1}{A} \int N u_{x} \partial A
\end{aligned}
$$

The Thermal Enhancement Factor (TEF) is defined as the ratio of the heat transfer coefficient of an augmented surface, $h$ to that of a smooth surface, $h_{0}$, at an equal pumping power and given by:

$$
T E F=\left.\frac{h}{h_{0}}\right|_{p p}=\left.\frac{N u}{N u_{0}}\right|_{p p}=\left(N u / N u_{0}\right) /\left(f / f_{0}\right)^{1 / 3}
$$

where, $N u_{0}$ and $f_{0}$ stand for Nusselt number and friction factor for the plain square channel, respectively.

\section{Results and Discussion}

\section{Flow Configurations and Heat Transfer Characteristics}

The flow configurations are reported in term of streamlines in transverse planes as Fig. 2, while the 
heat transfer characteristics are presented in forms of contour temperature in transverse planes and contours of local Nusselt number as Fig. 3 and 4, respectively.

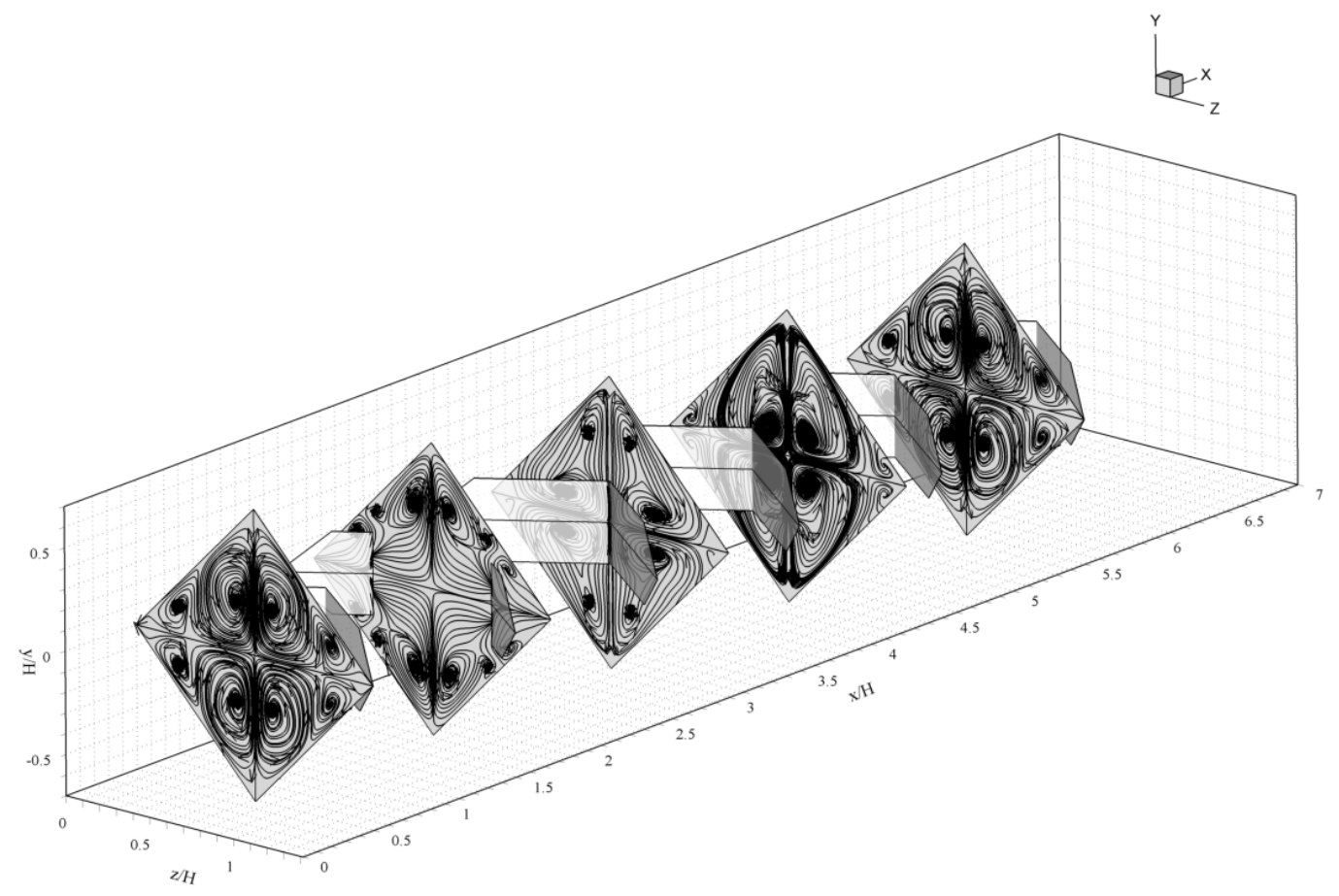

(a)

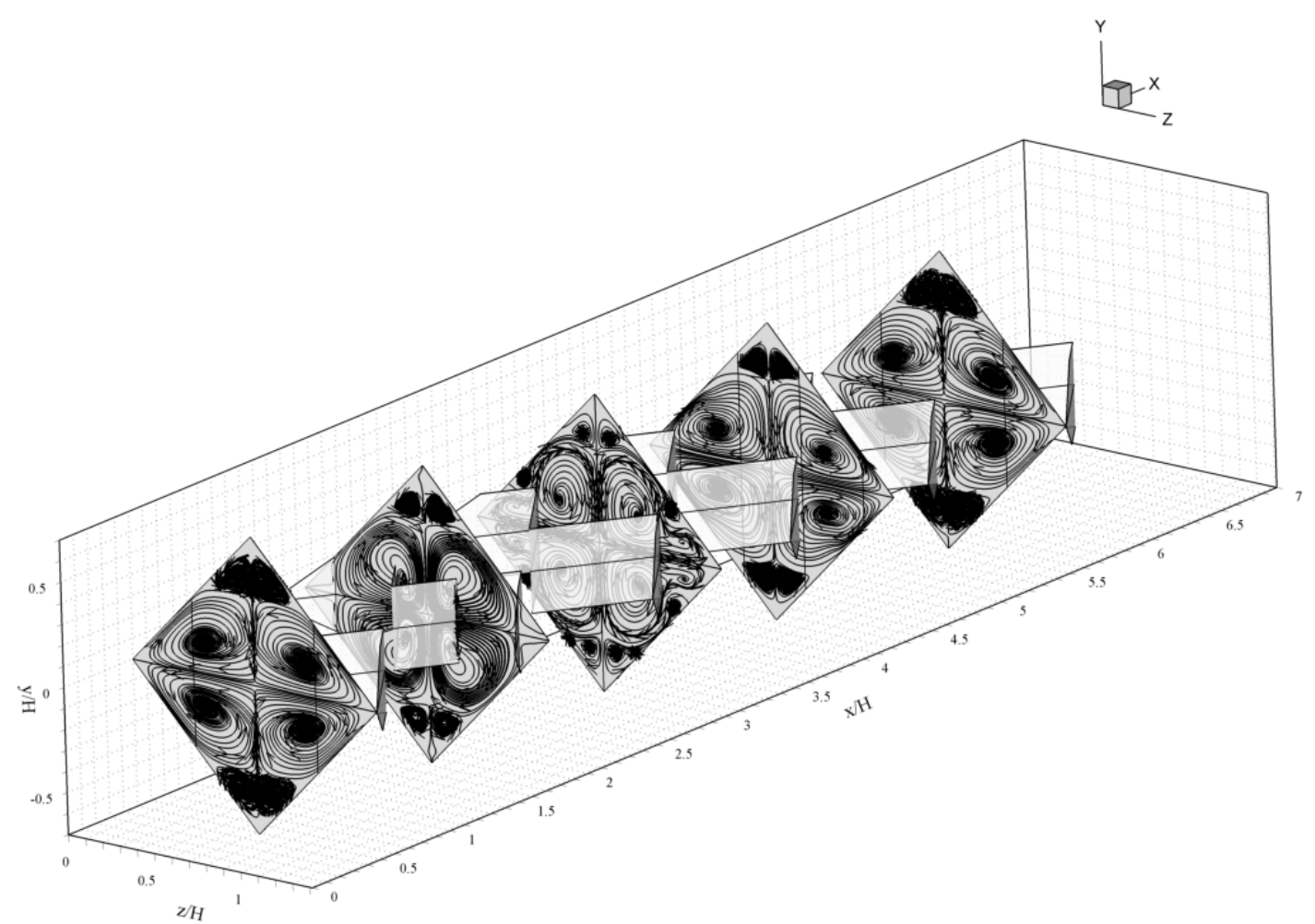

(b)

Fig. 2. Streamlines in transverse planes for (a) $R V$ and (b) $R D V$ at $R e=1200$ and $B R=0.20$ 


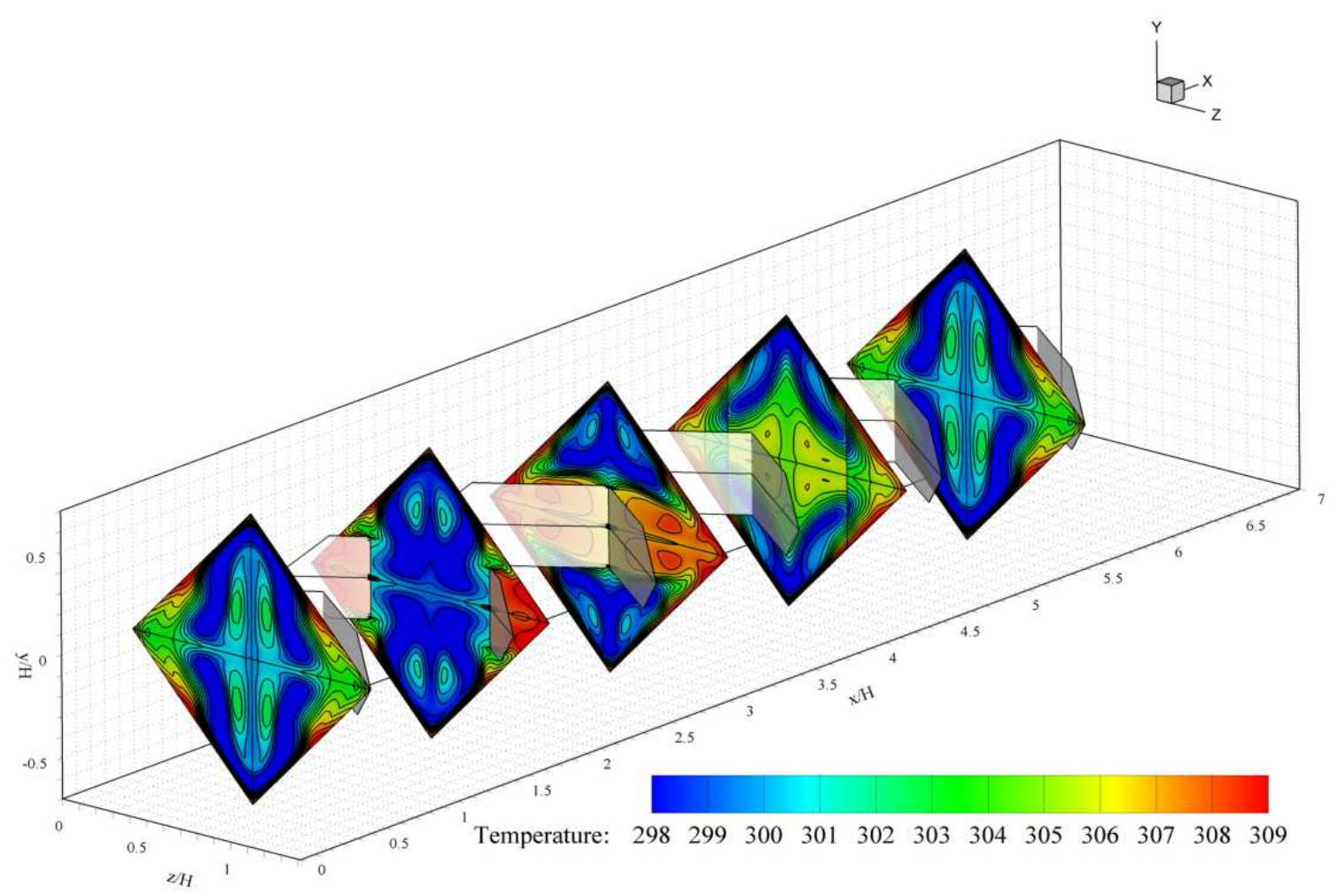

(a)

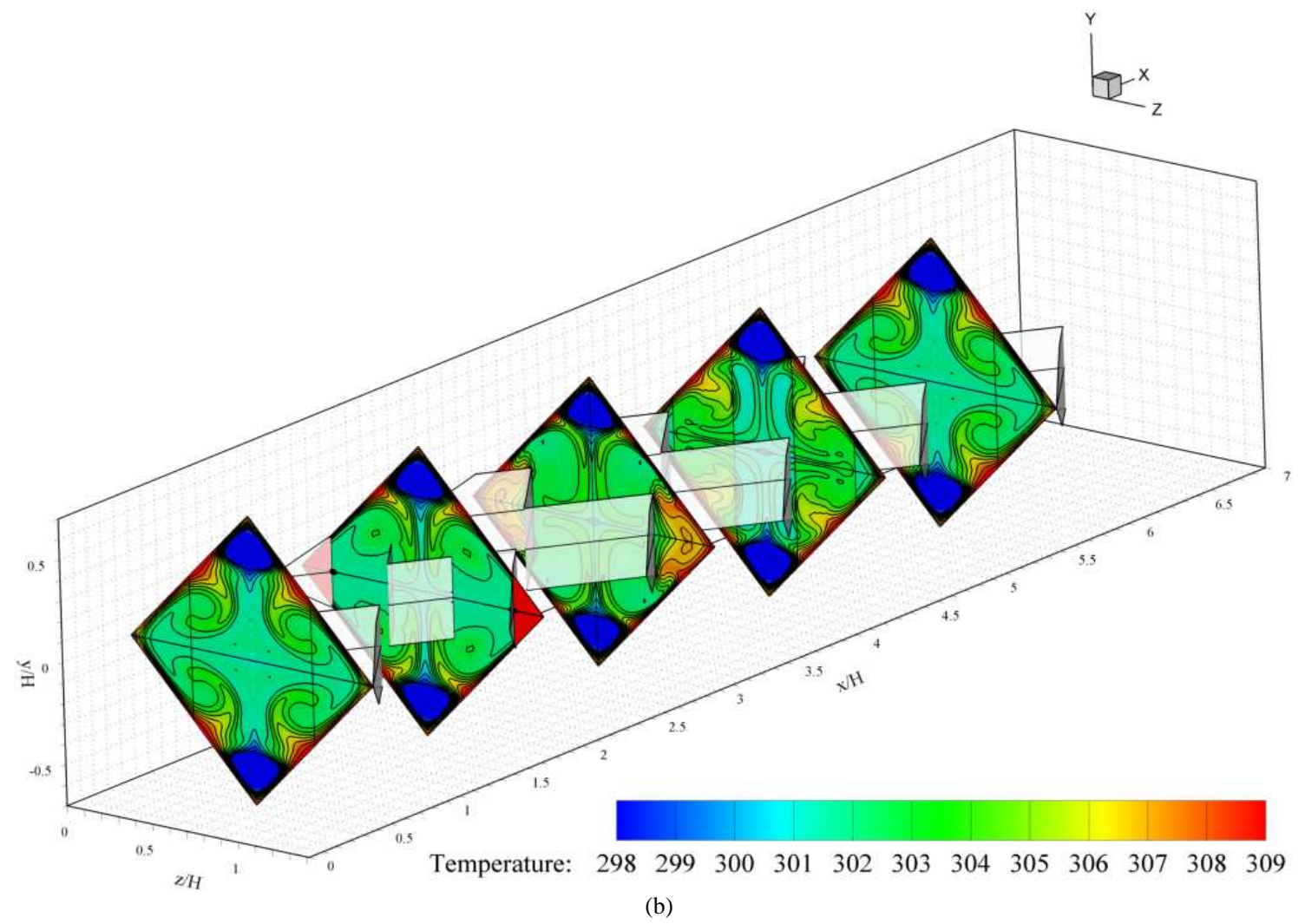

Fig. 3. Temperature contours in transverse planes for (a) RV and (b) $R D V$ at $R e=1200$ and $B R=0.20$ 

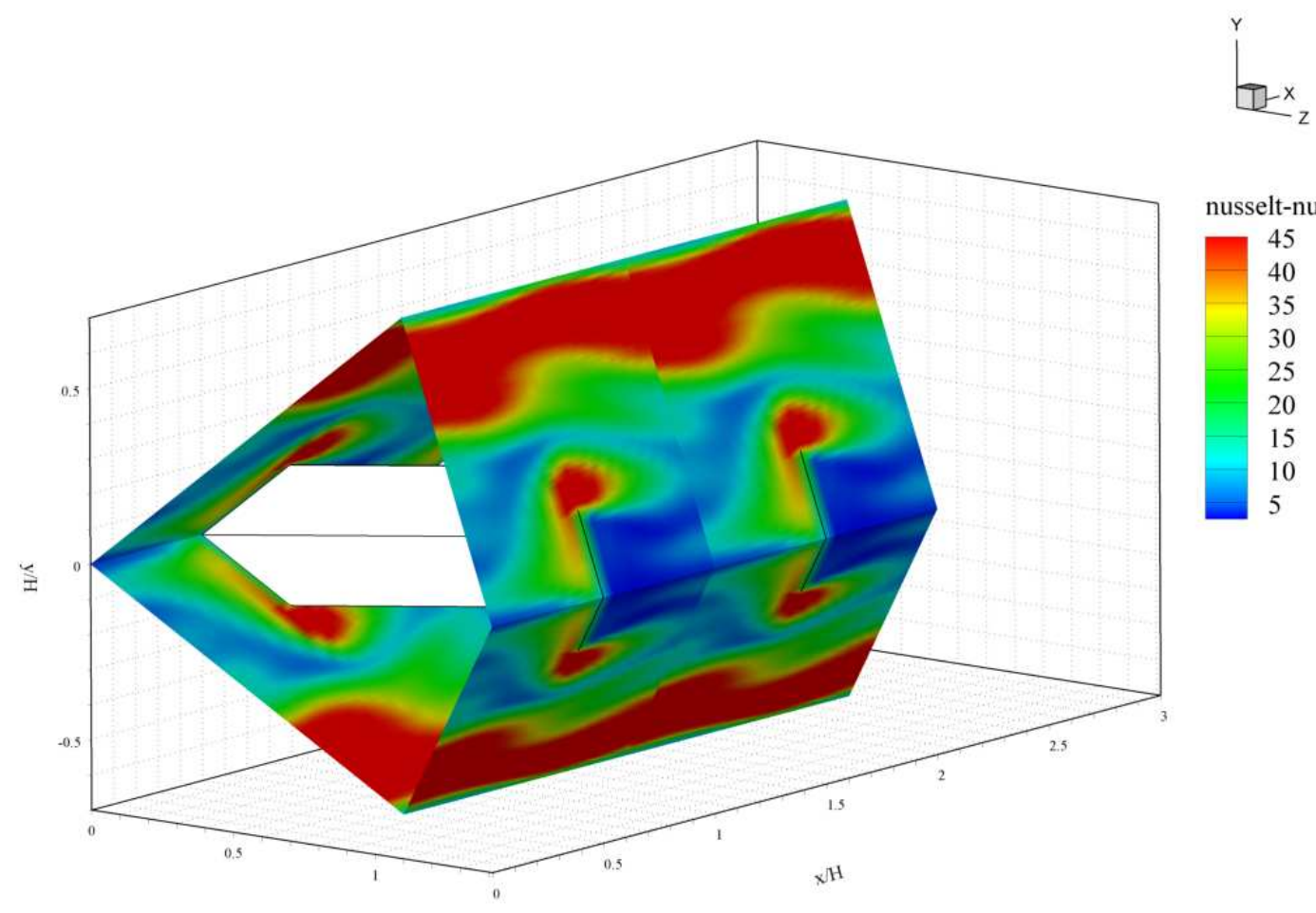

nusselt-number

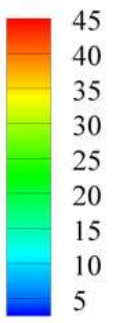

$z / H$

(a)
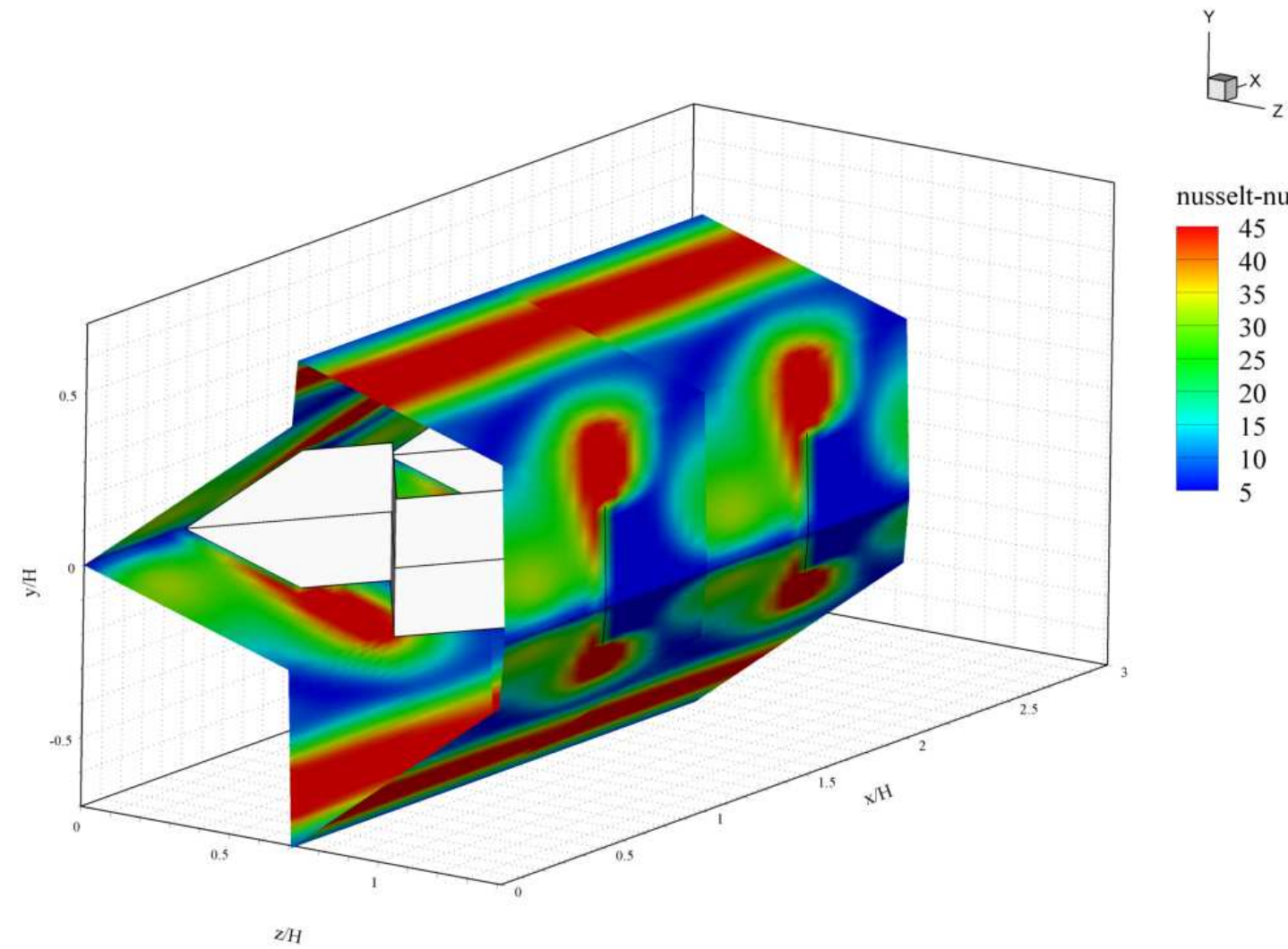

nusselt-number

\begin{tabular}{|l|}
\hline 45 \\
40 \\
35 \\
30 \\
25 \\
20 \\
15 \\
10 \\
5
\end{tabular}

(b)

Fig. 4. $\mathrm{Nu}_{\mathrm{x}}$ contours for (a) $\mathrm{RV}$ and (b) $\mathrm{RDV}$ at $\mathrm{Re}=1200$ and $\mathrm{BR}=0.20$ 
Figure $2 \mathrm{a}$ and $\mathrm{b}$ present the streamlines in transverse planes for RV and RDV, respectively, at $\mathrm{Re}=800$ and $\mathrm{BR}=0.2$. There are found that the inserted $\mathrm{RV}$ and $\mathrm{RDV}$ can change the flow field in comparison with the smooth square channel. The counter-rotating flow with commonflow-down is appearing for RV case when considering at the lower part of the main vortex. The similar flow structure with different rotating direction is found in case RDV. The vortex flows for RV are seen to be full filled of the transverse planes while the RDV provide a smaller size, but give the small vortices on both the upper and lower corner of the tested channel.

Figure $3 \mathrm{a}$ and $\mathrm{b}$ show the heat transfer behavior in the form of temperature in transverse planes for RV and RDV, respectively. As seen, on both the RV and RDV help to mixing the fluid flow between core and near the wall regimes. The RV case performs better mixing of the fluid flow than the RDV case.

Figure $4 \mathrm{a}$ and $\mathrm{b}$ display the $\mathrm{Nu}_{\mathrm{x}}$ contours on the square channel walls for RV and RDV, respectively, at $\mathrm{BR}=0.2$ and $\mathrm{Re}=800$. The uses of $\mathrm{RV}$ and $\mathrm{RDV}$ perform higher heat transfer rate than the smooth square channel. The peak regimes are found similarly. It is noted that the regimes where produce the lower heat transfer rate are found in case RDV, considering the blue contours over the channel walls.

\section{Performance Assessment}

The performance evaluations are presented for heat transfer rate, pressure loss and thermal performance in forms of Nusselt number ratio, $\mathrm{Nu} / \mathrm{Nu}_{0}$, friction factor ratio, $\mathrm{f} / \mathrm{f}_{0}$ and thermal enhancement factor, TEF, respectively. Figure $5 \mathrm{a}$ and $\mathrm{b}$ present the $\mathrm{Nu} / \mathrm{Nu}_{0}$ versus Reynolds number and $\mathrm{Nu} / \mathrm{Nu}_{0}$ versus $\mathrm{BR}$, respectively, for $\mathrm{RV}$ and $\mathrm{RDV}$. In general, the increasing Reynolds number and BR result in the increasing heat transfer rate for all cases. At $\mathrm{BR}=$ 0.30 , the RV performs higher heat transfer rate than the RDV around 2 times. For $0.05 \leq \mathrm{BR} \leq 0.15$, the RDV provides higher heat transfer rate than the RV case but the reverse trends present when $\mathrm{BR}>0.15$.

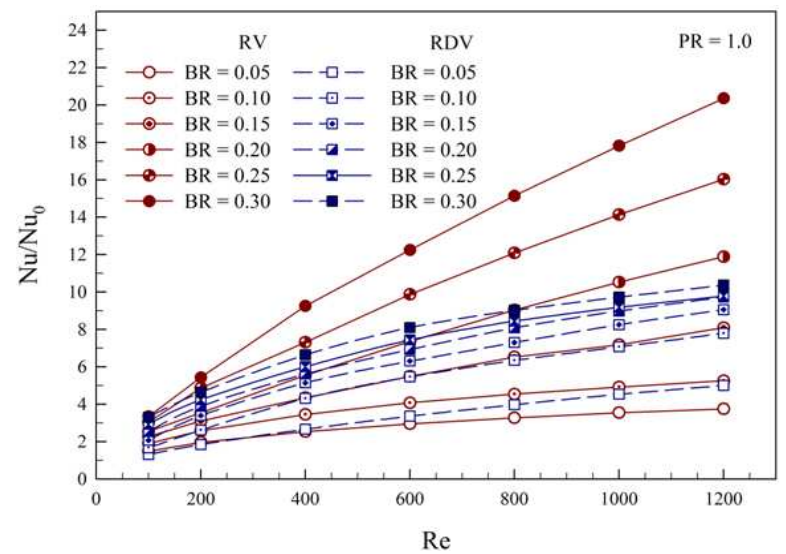

(a)

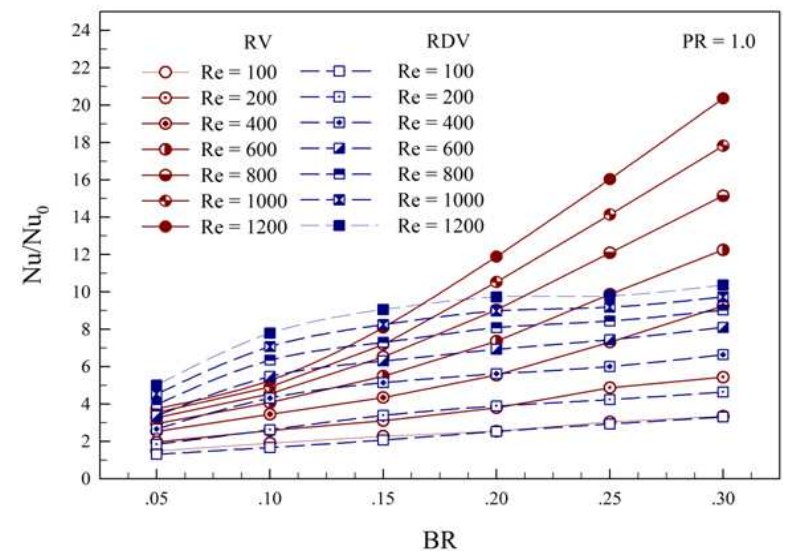

(b)

Fig. 5. (a) The variation of $\mathrm{Nu} / \mathrm{Nu}_{0}$ with Reynolds number and (b) The variation of $\mathrm{Nu} / \mathrm{Nu}_{0}$ with $\mathrm{BRs}$

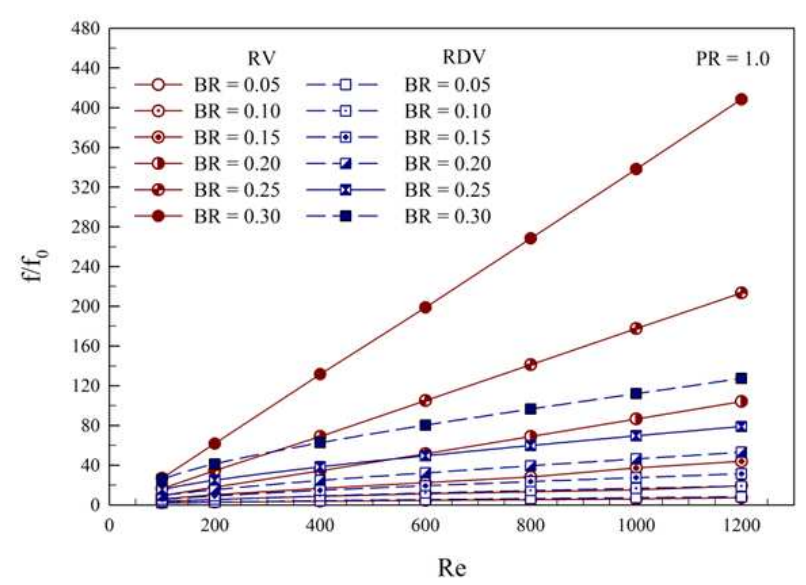

(a)

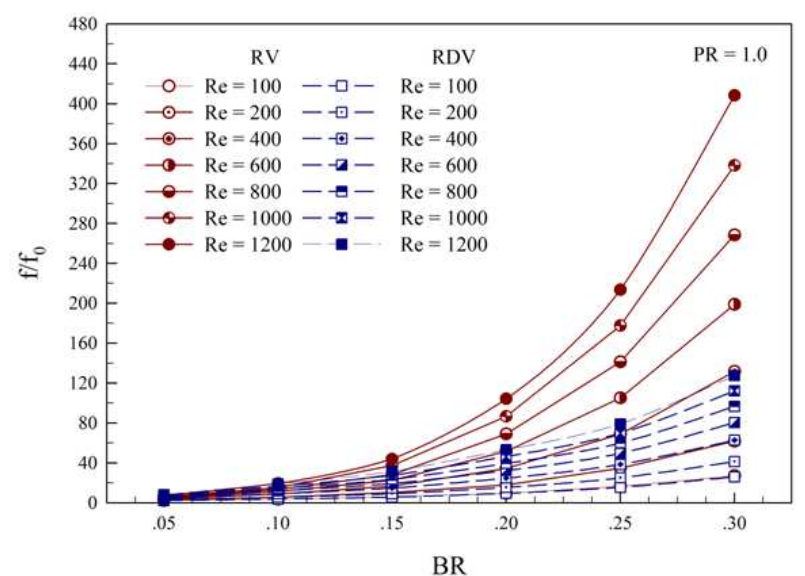

(b)

Fig. 6. (a) The variation of $f / f_{0}$ with Reynolds number and (b) The variation of $f / f_{0}$ with BRs 


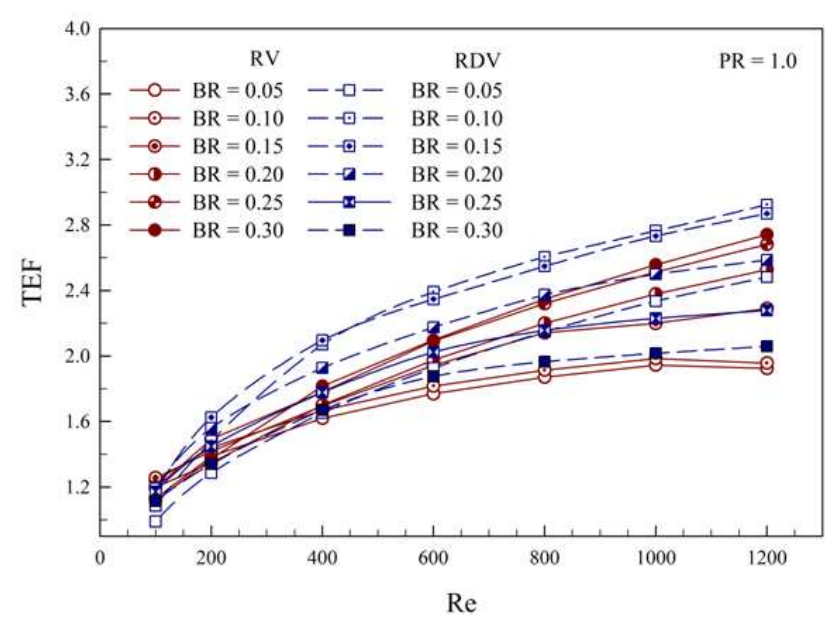

(a)

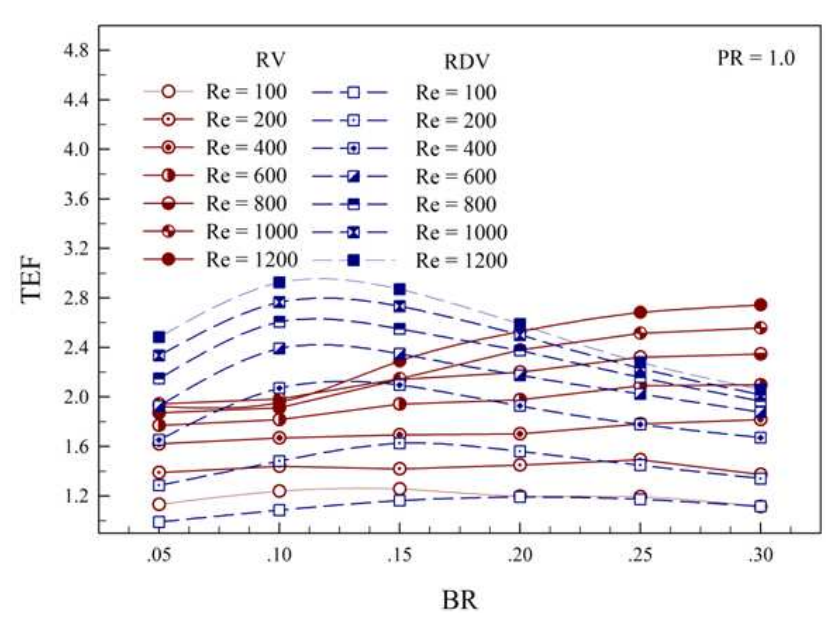

(b)

Fig. 7. (a) The variation of TEF with Reynolds number and (b) The variation of TEF with BRs

The uses of RV and RDV show the heat transfer rate around 1-20.5 and 1-10.5 times over the smooth square channel, respectively. Figure $6 \mathrm{a}$ and $\mathrm{b}$ show the $\mathrm{f} / \mathrm{f}_{0}$ with $\mathrm{Re}$ and the $\mathrm{f} / \mathrm{f}_{0}$ with $\mathrm{BR}$, respectively, for $\mathrm{RV}$ and $\mathrm{RDV}$ cases. The rising Reynolds number and the blockage ratios effect for the increasing friction factor values, especially, at $\mathrm{BR}>0.2$ for $\mathrm{RV}$ case. The friction factors are around 1-120 and 1-430 for RV and RDV, respectively. The thermal enhancement factors are presented in Fig. 7a and b, respectively, for RV and RDV. The uses on both cases give the TEF around 1-2.6 and 1-2.95 for RV and RDV, respectively. The optimum points are found at $\mathrm{BR}=0.10, \mathrm{Re}=1200$ for $\mathrm{RDV}$ case.

\section{Conclusion}

The thermal performance assessments for laminar forced convection in a square channel with $\mathrm{RV}$ and RDV generators are presented numerically in a three dimensional. The effects of BRs on flow configurations and heat transfer characteristics of Reynolds number, $\mathrm{Re}=100-1200$ are investigated. The summarizations are as follows:

- The rising Reynolds number and BR provide increasing heat transfer rate and friction factors in all cases

- The augmenting heat transfer rate is around 1-20.5 and 1-10.5 for RV and RDV, respectively, while the friction factor has seemed to be around 1-430 and 1120

- The thermal enhancement factor is around 1-2.6 and 1-2.95 for RV and RDV, respectively. The optimum $\mathrm{TEF}$ is found at $\mathrm{BR}=0.10$ for RDV case at the highest Reynolds number, $\operatorname{Re}=1200$

\section{Acknowledgement}

The authors would like to thank King Mongkut's Institute of Technology Ladkrabang (KMITL) research fund for financial supports.

\section{Author's Contributions}

All authors equally contributed in this work.

\section{Ethics}

This article is original and contains unpublished material. The corresponding author confirms that all of the other authors have read and approved the manuscript and no ethical issues involved.

\section{References}

Boonloi, A. and W. Jedsadaratanachai, 2013. 3D Numerical study on laminar forced convection in V-baffled square channel. Am. J. Appl. Sci., 10: 1287-1297. DOI: 10.3844/ajassp.2013.1287.1297

Boonloi, A., 2014. Effect of flow attack angle of V-ribs vortex generators in a square duct on flow structure, heat transfer and performance improvement. Modell. Simulat. Eng., 2014: 985612-985622. DOI: $10.1155 / 2014 / 985612$

Incropera, F.P. and P.D. Dewitt, 2006, Introduction to Heat Transfer. 5rd Edn., John Wiley and Sons, Hoboken, NJ., ISBN-10: 0471457272, pp: 912.

Jedsadaratanachai, W. and A. Boonloi, 2013. Energy performance improvement, flow behavior and heat transfer investigation in a circular tube with V-downstream discrete baffles. J. Math. Stat., 9: 339-348. DOI: 10.3844/jmssp.2013.339.348 
Jedsadaratanachai, W. and A. Boonloi, 2014. Effect of twisted ratio on flow structure, heat transfer and thermal improvement in a circular tube with single twisted tape. J. Math. Stat., 10: 80-91.

DOI: $10.3844 /$ jmssp.2014.80.91

Jedsadaratanachai, W., S., Suwannapan and P. Promvonge, 2011. Numerical study of laminar heat transfer in baffled square channel with various pitches. Energy Procedia, 9: 630-642. DOI: $10.1016 / j$. egypro.2011.09.073

Kwankaomeng, S. and P. Promvonge, 2010. Numerical prediction on laminar heat transfer in square duct with $30^{\circ}$ angled baffle on one wall. Int. Commun. Heat Mass Transfer, 37: 857-866.

DOI: $10.1016 /$ j.icheatmasstransfer.2010.05.005

Patankar, S.V., 1980, Numerical Heat Transfer and Fluid Flow. 1st Edn., McGraw-Hill, New York, ISBN-10: 0070487405, pp: 197.

Promvonge, P. and S. Kwankaomeng, 2010. Periodic laminar flow and heat transfer in a channel with $45^{\circ}$ staggered V-baffles. Int. Commun. Heat Mass Transfer, 37: 841-849.

DOI: $10.1016 /$ j.icheatmasstransfer.2010.04.002
Promvonge, P., S. Sripattanapipat and S. Kwankaomeng, 2010b. Laminar periodic flow and heat transfer in square channel with $45^{\circ}$ inline baffles on two opposite walls. Int. J. Therm. Sciences, 49: 963-975.

DOI: $10.1016 /$ j.ijthermalsci.2010.01.005

Promvonge, P., W. Jedsadaratanachai and S. Kwankaomeng, 2010a. Numerical study of laminar flow and heat transfer in square channel with $30^{\circ}$ inline angled baffle turbulators. Appl. Therm. Eng., 30: 1292-1303.

DOI: 10.1016/j.applthermaleng.2010.02.014

Promvonge, P., W. Jedsadaratanachai, S. Kwankaomeng and C. Thianpong, 2012. 3D simulation of laminar flow and heat transfer in V-baffled square channel. Int. Commun. Heat Mass Transfer, 39: 85-93. DOI: 10.1016/j.icheatmasstransfer.2011.09.004

Roache, P.J., 1998. Verification and Validation in Computational Science and Engineering. 1st Edn., Hermosa Publishers, Albuquerque, NM, ISBN-10: 0913478083, pp: 464. 